\title{
Lepista polygonarum and Prunulus lammiensis, two new combinations in the Agaricales
}

\author{
HARRI HARMAJA
}

\begin{abstract}
HARMAJA, H. 2002: Lepista polygonarum and Prunulus lammiensis, two new combinations in the Agaricales. - Karstenia 42: 23-25. Helsinki. ISSN 0453-3402.

Clitocybe polygonarum Laursen, O.K. Miller \& H.E. Bigelow (Tricholomataceae) from arctic Alaska is transferred to Lepista (Fr.) W.G. Sm. as Lepista polygonarum (Laursen, O.K. Miller \& H.E. Bigelow) Harmaja, comb. nov. The taxonomy of the species group that includes L. polygonarum is briefly discussed. The name Tricholoma multiforme has been incorrectly attributed to Romell as a new species. It is not synonymous with L. polygonarum. The nomenclature of Agaricus multiformis Schaeff. and Cortinarius multiformis Fr. is clarified. Mycena lammiensis Harmaja (Mycenaceae) is transferred to Prunulus Murrill, a segregate genus comprising species around $M$. pura (Pers. : Fr.) Kumm., as Prunulus lammiensis (Harmaja) Harmaja.
\end{abstract}

Key words: Agaricales, arctic tundra, nomenclature, taxonomy

Harri Harmaja, Botanical Museum, Finnish Museum of Natural History, P.O. Box 47, FIN-00014 University of Helsinki, Finland www.helsinki.fi/people/harri.harmaja'

Lepista polygonarum (Laursen, O.K. Miller \& H.E. Bigelow) Harmaja, comb. nov.

Basionym: Clitocybe polygonarum Laursen, O.K. Miller \& H.E. Bigelow, Canad. J. Bot. 54: 976. 1976. - Isoparatype examined: U.S.A. Alaska. Barrow Co.: US IBP Tundra Biome Site 4, on dry polygon, 23.VIII.1974, O.K. Miller Jr. \& G.A. Laursen 11873 (H; paratype in VPI, another isoparatype in ALA).

Laursen et al. (1976) include a good description and illustrations of this agaric species which is most characteristic as to morphology, habitat and distribution. Following the philosophy of Bigelow and Smith (1969), the species was assigned to Clitocybe (Fr.) Staude. Harmaja (1978) subsequently reported that the verruculose spore wall of this fungus is (strongly) cyanophilic, indicating that the wall includes an outer myxosporium layer, and considered that the species should be transferred to Lepista (Fr.) W.G.
$\mathrm{Sm}$. He also reported small, weakly staining carminophilic/siderophilic granules in the young basidia of the species. The possible taxonomic relevance of the granules cannot be judged at present.

Gulden (1983) stated that Clitocybe polygonarum -like Lepista polycephala Harmaja described from Finland (Harmaja 1976) - are later synonyms of "Tricholoma multiforme Romell" (Romell 1911). Accordingly, Gulden transferred T. multiforme to Lepista and placed both C. polygonarum and L. polycephala in synonymy of "Lepista multiformis (Romell) Gulden" ('multiforme'). However, an examination of the cited paper of Romell, dealing with macrofungi of Swedish Lapland, reveals that he did not publish a new species according to any edition of the Code of nomenclature, either purposely or unintentionally. The name concerned is instead a new combination Tricholoma multiforme (Schaeff.) Romell (basionym Agaricus multiformis Schaeff. 1774: 9 [1762: pl. 14]). Romell (1911: footnote p. 3) writes 
in English that as the fungus "seems to agree tolerably in this respect with Tricholoma pes caprae var. multiformis (as understood by MASSEY in COOKE, Illustr. t. 946), I have named it Trich. multiforme. Whether it is quite identical, however, either with MASSEY's or with SCHAEFFER's plant of that name I am unable at present to decide." Table no. 946 in Cooke (1888) illustrates Agaricus [subg. Tricholoma] pescaprae Fr. var. multiformis (Schaeff.) Cooke (the exact name including the varietal epithet is only given in the index of the work). The unfortunate expression "I have named it ..." means here "I have identified it as...". In his index of specific names mentioned in the paper, Romell (1911) lists new names (species) in bold: e.g., the epithet 'pubifolium' is in bold and Romell is indeed considered to have described the new species Tricholoma pubifolium Romell in this paper. On the contrary, the epithet 'multiforme' appears in the normal font like the other old epithets. The idea of Romell is obvious, and Article 33 of the International Code of Botanical Nomenclature (Greuter \& al. 2000), especially Art. 33.2 and 33.6(d), indicate that the author made a new combination instead of having described a new species, hence the name is T. multiforme (Schaeff.) Romell, and not "T. multiforme Romell". As such, typification is linked to the basionym, Agaricus multiformis Schaeff. and not Romell's collections. Gulden (1983: 65) had "neotypified" T. multiforme by Romell materials collected in 1916 near Abisko, Sweden. This neotypification is of course incorrect.

Romell's fungus, growing along a railway in the subalpine Betula zone in northernmost Sweden, may be identical with Lepista polygonarum or it may belong to some closely related species. The fungi (or fungus) of Schaeffer and Cooke originate from temperate Europe and are paler than the northern fungi, and the gills are somewhat sinuate; I do not take any final position as to the identity of these southern taxa, except to exclude them from the concept of the northern species.

Lepista polycephala, described a few months later than Clitocybe polygonarum, is distinct from the latter: the pileus of the former is non-hygrophanous and paler brown, the lamellae are truly though shortly decurrent, the spore size and ornamentation display subtle differences, and the habitat ecology and distribution appear different.

For the time being, it would appear wisest to restrict the concept of Lepista polygonarum to fungi that grow in the arctic tundra of Alaska and Canada (Bathurst I., Nunavut: Redhead 1989, as L. 'multiforme'). According to the original paper (Laursen \& al. 1976) the species was not observed in subalpine tundra of Alaska or neighbouring areas. This group of brown cespitose species is taxonomically difficult and apparently still comprises undescribed species. Differentlooking specimens have been collected almost throughout Finland: from the area of the oak (Quercus robur) to the northern boreal zone (but apparently not from subalpine or alpine conditions). Esteve-Ravantós \& Villarreal (2000) suggest that Lepista rickenii Sing. would be the same species as 'Lepista multiforme' of Gulden (and thus also synonymous with Clitocybe polygonarum and L. polycephala). However, to my judgement $L$. rickenii is morphologically distinct from $L$. polygonarum. Moreover, the type locality of $L$. rickenii at the former Finnish-Russian border lies at the northern edge of the distribution area of the oak (Quercus robur), i.e. in considerably warmer climatic conditions. Admittedly, however, the characters of L. polycephala remind fairly much those of $L$. rickenii.

Besides Agaricus multiformis Schaeff., a later homonym, A. multiformis Fr., has been described. As the latter was not used in the sanctioning publications of Fries, it is an illegitimate later homonym. The correct name and author citation of the latter fungus is Cortinarius multiformis Fr. 1838 (Epicr. Syst. Mycol.), [unintentional] nomen novum (= Agaricus multiformis Fr. 1818, Observ. Mycol. 2; non Agaricus multiformis Schaeff. 1774 [1762], Fungorum ... icones). In the meantime, in his sanctioning publications, Fries treated his species as a synonym of another Cortinarius species so it was never sanctioned. Schaeffer's species was always treated by Fries as a synonym in Agaricus subg. Tricholoma. 
Prunulus lammiensis (Harmaja) Harmaja, comb. nov.

Basionym: Mycena lammiensis Harmaja, Karstenia 25: 44. 1985. - Holotype from Finland $(\mathrm{H})$.

Redhead \& al. (2001) reported that molecular evidence indicates that the genus Mycena (Pers. : Fr.) Roussel (Mycenaceae) is polyphyletic. For instance, the group of species around $M$. pura (Pers. : Fr.) Kumm. would appear to deserve a generic rank and the name Prunulus Gray 1821 was found to be the correct one for the segregate genus which these species constitute.

Of the species of this taxonomic group, $M$. lammiensis Harmaja has not yet been combined with the generic name Prunulus Gray. Therefore, the new combination needed is made here. A photograph of fresh fruit bodies of $P$. lammiensis and the characters differentiating it from its close relatives P. pelianthinus (Fr. : Fr.) James E. Johnson, Vilgalys \& Redhead and P. rutilantiformis Murrill are given in Harmaja (1985, as Mycena).

Nordic Macromycetes (Hansen \& Knudsen 1992) treats both P. pelianthinus and P. lammiensis (under Mycena). Strangely enough, however, the first-named species, with a southern distribution and commonly associated with Fagus or Quercus, is said to have some deviating northern and/or occurrences associated with Alnus. Such occurrences fit better with the properties of $P$. lammiensis and it would appear that they in fact represent that species.

Acknowledgements: Professor Teuvo Ahti (Helsinki) and Dr. Scott A. Redhead (Ottawa, Canada) made valuable improvements to the manuscript.

\section{References}

Bigelow, H.E. \& Smith, A.H. 1969: The status of Lepista - a new section of Clitocybe. - Brittonia 21: 144 177.

Cooke, M.C. 1888: Illustrations of British Fungi (Hymenomycetes). No. 60. - Williams \& Norgate, London.

Esteve-Ravantós, F. \& Villarreal, M. 2000: Type study of Lepista rickenii (Tricholomatales) and description of L. panaeolus var. paxilloides var. nov. - Mycotaxon 76: 399-09.

Greuter, W., McNeill, J., Barrie, F.R., Burdet, H.M., Demoulin, V., Filgueiras, T.S., Nicolson, D.H., Silva, P.C., Skog, J.E., Trehane, P., Turland, N.J. \& Hawksworth, D.L. (eds.) 2000: International Code of Botanical Nomenclature (Saint Louis Code). Adopted by the Sixteenth International Botanical Congress St. Louis, Missouri, July-August 1999. - Regnum Veg. 138: $1-474$.

Gulden, G. 1983: Studies in Lepista (Fr.) W.G. Smith section Lepista (Basidiomycotina, Agaricales). Sydowia 36: 59-74.

Hansen, L. \& Knudsen, H. (eds.) 1992: Nordic Macromycetes. Vol. 2. Polyporales, Boletales, Agaricales, Russulales. - 474 pp. Nordsvamp, Copenhagen.

Harmaja, H. 1976: A further revision of the generic limit between Lepista and Clitocybe. - Karstenia 15: 13-15.

Harmaja, H. 1978: The division of the genus Lepista. Karstenia 18: 49-54.

Harmaja, H. 1985: Studies on white-spored agarics. Karstenia 25: 41-46.

Laursen, G.A., Miller, O.K., Jr. \& Bigelow, H.E. 1976: A new Clitocybe from the Alaskan Arctic. - Canad. J. Bot. 54: 976-980.

Redhead, S.A. 1989: A biogeographical overview of the Canadian mushroom flora. - Canad. J. Bot. 67: 30033062.

Redhead, S.A., Vilgalys, R., Moncalvo, J.-M., Johnson, J. \& Hopple, J.S. 2001: Coprinus Pers. and the disposition of Coprinus species sensu lato. - Taxon 50: 203-241.

Romell, L. 1911: Hymenomycetes of Lappland. - Ark. Bot. 11(3): 1-35, 2 pls.

Schaeffer, J.C. 1762: Fungorum qui in Bavaria et Palatinatu circa Ratisbonam nascuntur icones nativis coloribus expressae. Vol. I. Pls. 1-100. Zunkel, Ratisbona.

Schaeffer, J.C. 1774: Fungorum qui in Bavaria et Palatinatu circa Ratisbonam nascuntur icones nativis coloribus expressae. Vol. IV. 136 pp. + P1s. 301-330. Zunkel, Ratisbona. 